\title{
A Critical Appraisal of the Right of Inheritance of Children Born Out of Wedlock
}

\author{
Michael Akpa Ajanwachuku \\ Faculty of Law, Ebonyi State University \\ P.M.B. 053, Abakaliki, Ebonyi State, Nigeria. \\ Tel./Fax: +234-703-3865888E-mail: majanwachuku@yahoo.com \\ Submitted: Nov 16, 2015; Reviewed: Dec 22, 2015; Accepted: Jan 4, 2016
}

\begin{abstract}
The phenomenon of the so-called bastard children has growth astronomically worldwide. In Nigeria, the rights of children born out of wedlock to inherit their biological fathers who died intestate was wholly dependent on the acknowledgement of paternity. This paper attempts to unravel the recent development in the law of inheritance in Nigeria with respect to children born out of wedlock. It concludes from the review of case laws in Nigeria that there is a significant progressive development of the law in Nigeria. Absent acknowledgement of paternity, children born out of wedlock may now inherit their biological fathers if they can provide other evidence of paternity, including the use of DNA technology.
\end{abstract}

Keywords: Inheritance; Children; Paternity

DOI: http://dx.doi.org/10.20956/halrev.v1n1.192

\section{INTRODUCTION}

One of the incidents of father-child relationship in Nigeria is the right of the child to inherit the property of the father, on the death of the father. Where the deceased has more than a child, the children are entitled to inherit his property on his death. The sex of a child is immaterial, so that in inheritance, females have the right just as the males, to inherit in and partake of the estate of their late father.

The right of inheritance is also available to children born out of wedlock, but for that right to enure, the paternity of such chil- dren must have been acknowledged by the intestate.

A critical review of the right of inheritance of children born out of wedlock has shown that today, children who can prove that the intestate was their biological father can partake of the estate of such intestate. Interestingly, judicial authorities on proof of paternity in order to be entitled to inheritance have revealed that any minimal proof is sufficient. Additionally, establishing paternity is now statutory in Nigeria.

The objective of this work is to critically review these judicial authorities and 
the statutory provision.

The relevance of this work is to show that in Nigeria, the right of a child born out of wedlock to inherit from the intestate of the deceased biological father enures not only when the paternity of the child has been acknowledged by the deceased but on proof that the child was the biological child of the deceased. The theoretical framework of this paper shall be a critical review of the already highlighted progress made in this area of law.

\section{ANALYSIS AND DISCUSSION}

\section{Right of Inheritance of Children Born out of Wedlock: A Critical Review}

The right of inheritance of children born in the matrimonial home is not a subject matter of debate, doubt or controversy. For several years, the right was reserved for the male children, ${ }^{1}$ to the exclusion of the female children. The reason for the discrimination is simply that females would marry and form a new family and so have no need to partake of the estate of their family of birth that they would someday abandon ${ }^{2}$. This reason did not recognize that there was need for them to partake of the estate with their male sibling(s) until they get married. The reason did not also contemplate that the female child may not get married after all.

The discriminatory practice against women in inheritance matters is quite

\footnotetext{
This is the state of affairs in Northern, Southern and Eastern Nigeria. In some cultures, especially among the Ibo of Eastern Nigeria, the males who inherit are the first male children, to the exclusion of other male siblings of theirs. Among some cultures of the Ibo, the first male child inherits the property of the father, to the exclusion of all other male siblings, while the last male child inherits the property of the mother to the exclusion of all other male siblings.

2 However, in Western Nigeria, females and males inherit in the estate of their deceased father.
}

prominent amongst the Ibo tribe of Eastern Nigeria. However, since the Supreme Court decision in Ukeje v. Ukeje, ${ }^{3}$ that discriminary practice amongst the Ibo actuated by native law and custom has become an aspect of history. In the words of Onnoghen J.S.C, "the Ibo customary law which disentitles a female child from partaking in her deceased father's estate is ... void"4.

Although this decision was reached on a rule of customary law amongst the Ibo (that daughters are not entitled to inherit from the estate of their late father), the pronouncement applies to all rules of customary law in Nigeria that discriminate against daughters in inheritance. This is so because the pronouncement was made on the reasoning that such discriminatory practice

...is in breach of section 42(1) and (2) of the Constitution of the Federal Republic of Nigeria, 1999, a fundamental rights provision guaranteed to every Nigerian",

From the decision in Ukeje v Ukeje, the law has now settled for non-discrimination against daughters, on inheritance matters.

\footnotetext{
(2014) 11 N.W.L.R (pt 1418) 384

Ibid., ratio 4

The said section 42 paragraph (1) \& (2) states thus: Paragraph (1): A citizen of Nigeria of a particular community, ethnic group, place of origin, sex, religion or political opinion shall not, by reason only that he is such a person: a) be subjected either expressly by, or in the practical application of, any law in force in Nigeria or any executive or administrative action of the Government, to disabilities or restrictions to which citizens of Nigeria of other communities, ethnic groups, places of origin, sex, religions or political opinions are not made subject; or b) be accorded either expressly by, or in the practical application of, any law in force in Nigeria or any such executive or administrative action, any privilege or advantage that is not accorded to citizens of Nigeria of other communities, ethnic groups, places of origin, sex, religions or political opinions; Paragraph (2): No citizen of Nigeria shall be subjected to any disability or deprivation merely by reason of the circum-
} stances of his birth. 
While the right of inheritance of children born in the matrimonial home is not a subject matter of debate, doubt or controversy for the obvious reason that they were born by the wife of the deceased living with the deceased as the husband, children born out of wedlock are not that lucky. By the fact that they were born out of wedlock and not in the matrimonial home, the deceased is not certainly and obviously known as their father. The deceased would only be known to be their biological father if he had acknowledged their paternity. Where therefore there is no acknowledgement, children born out of wedlock would not inherit of the estate of their deceased biological father.

Conversely, where there is an acknowledgement of the paternity of children born out of wedlock, they found their state as not less than or inferior to that of the children born in the matrimonial home. Both share the common feature of being the biological children of the intestate, the condition precedent to partaking in the estate of such intestate. Not only are children born out of wedlock whose paternity have been acknowledged entitled to partake of the estate of the deceased with those born in the matrimonial home ${ }^{6}$, they are entitled to partake with them in equal share.

According to the Court of Appeal ${ }^{7}$ in Okonkwo v. Okonkwo: ${ }^{8}$

By virtue of section 42 of the Constitution of the Federal Republic of Nigeria

\footnotetext{
"In Nigeria, once a father acknowledges the paternity of a child whether born in or out of wedlock, the child is regarded as a legitimate child is entitled to share in the estate of his/her father": Court of Appeal Enugu Division in Mgbodu v. Mgbodu (2015) 12 N.W.L.R (pt 1474) 415 ratio 3

Enugu Division

(2014) 17 N.W.L.R (pt 1435) 18
}

1999, children born out of wedlock but whose paternity was acknowledged by the intestate have equal share with the children of the marriage .

Having established that it is only an acknowledgement of the paternity of children born out of wedlock by the intestate that 'levels-up' such children with those born in the matrimonial home and bestows the right to equally share in the property of their common father, with those born in the matrimonial home one may state the obvious, that sometimes acknowledgement is not made by the intestate. Several reasons account for this, including:

i. That non-acknowledgement will obviate "the trouble the wife and children would make with him' on making the acknowledgement.

ii. That on making the acknowledgement the children born out of wedlock would want to partake in 'all the affairs of the family', including his burial, which the wife and children born in the matrimonial home would resist, thereby making his burial an object of quarrel and disagreement.

iii. That the deceased never even knew that he has the right to acknowledge his children born out of wedlock because in several tribes of Nigeria, including the Ibo of Eastern Nigeria, the Ibo custom is that a man is not entitled to the paternity of the children begotton from a woman on whom he paid no bride price.

\footnotetext{
Ratio 6, per Agube J.C.A, who read the leading judgment with whom Mshelia and Agim J.J. C.A unanimously agreed.
} 
iv. That the mother of the children never disclosed to the deceased that he was responsible for the pregnancies of the children, so that the deceased never at all knew that he was the biological father of any child outside his children of marriage.

v. That the deceased reserved the acknowledgement for a future date, but died before the future date.

Acknowledgement of paternity must be made by the intestate himself. Nobody can make an acknowledgement for or on behalf of an intestate. This has been illustrated in the case of Okonkwo v. Okagbue ${ }^{10}$. In that case, one Nnanyelugo Nnebedum Okonkwo died intestate in 1931 leaving as surviving sons, the appellant and his four brothers. He was also survived by two sisters (the $1^{\text {st }}$ and $2^{\text {nd }}$ respondents) who married the $3^{\text {rd }}$ respondent for him, thirty years after his death. The $3^{\text {rd }}$ respondent had six children that answer the name of the deceased as their surname and present themselves as the children of the deceased.

The appellant as the plaintiff sued at the High Court of Anambra State of Nigeria, sitting at Onitsha, ${ }^{11}$ seeking in the midst of other reliefs, an order of court that the six children were not those of the deceased and cannot inherit in the estate of the deceased. The plaintiff lost in the suit and appealed to the Court of Appeal ${ }^{12}$ where he also lost. He further appealed to the Supreme Court, where the appeal was allowed.

On acknowledgement of paternity of the six children of the $3^{\text {rd }}$ respondent as those

\footnotetext{
(1994) 9 N.W.L.R (Pt. 368) 301

Presided over by Nwokedi, J.

2 Enugu Division
}

of the deceased, Ogundare JSC stated as follows:

It cannot be contested that Okonkwo (deceased) could not be the natural father of these children. Yet the $1^{\text {st }}$ and $2^{\text {nd }}$ defendants would want to integrate them into his family ${ }^{13}$.

Furthermore, the learned Justice of the Supreme Court stated that it was better for the children to be informed of who their fathers are (were) rather than making them continue to believe that the deceased who was not their father, when he was not. In his words:

It is in the interest of the $3^{\text {rd }}$ defendant's children to let them know who their true fathers are (were) and not to allow them to live for the rest of their lives under the myth that they are the children of a man who died many decades before they were born ${ }^{14}$.

Again, where the deceased has not acknowledged the paternity of children, no amount of representation or claim that the children were those of the deceased would make them be. This played out in the case of Emodi $v$ Emodi.${ }^{15}$ In this case, the deceased (Nnanyelugo Umunna Emodi) got married to the $1^{\text {st }}$ respondent in 1977 but the marriage was dissolved by a High Court in 2000 . From 1982 to 2000 when the marriage was dissolved, the $1^{\text {st }}$ respondent and the deceased were living apart. There were no children of the marriage. On the death of the deceased in 2000 , the issue in contention in the suit was whether it was the $2^{\text {nd }}$ to $4^{\text {th }}$ respondents ${ }^{16}$ who claim to be the children of the deceased were entitled to Letters of Administration to

\footnotetext{
3 At page 343

At page 344

(2015) 2 N.W.L.R (Pt. 1443) 323

Born 1985, 1986 and 1989 respectively.
} 
administer the estate of the deceased or the appellants who were the deceased's blood relations. The High Court (of Anambra State of Nigeria sitting at Awka) gave judgment in favour of the respondents, reasoning that the $2^{\text {nd }}$ to $4^{\text {th }}$ respondents were the children of the deceased. The judgment of the court was informed by the following pieces of evidence from the $2^{\text {nd }}$ to $4^{\text {th }}$ respondents:

(i) That at the ceremony performed on the $14^{\text {th }}$ and $15^{\text {th }}$ days of December, 1993 to initiate the deceased into Agbalanze Society of Onitsha, the $2^{\text {nd }}$ and $3^{\text {rd }}$ respondents performed the "iti obi" by embracing the deceased, which under Onitsha native law and custom meant that they were the eldest son and daughter, respectively of the deceased.

(ii) That when the deceased was alive, he was responsible for the education and welfare of the $2^{\text {nd }}$ to $4^{\text {th }}$ respondents particularly during Christmas and other activities.

(iii) That during the funeral rites of the deceased, the $2^{\text {nd }}$ and $3^{\text {rd }}$ respondents were called out as the eldest son and daughter respectively, of the deceased and that they received the purse presented by the Vice President of Agbalanze Onitsha Society.

(iv) That the deceased, who was a civil servant, changed his next of kin, from his father, to the $2^{\text {nd }}$ respondent, as the eldest son.

The appellants appealed to the Court of Appeal ${ }^{17}$ where the court allowed the appeal, holding inter alia that:

17 Enugu Division
In so far as the respondents have sought the grant of letters of administration in this case upon the basis that they are the deceased's children, which they have failed to establish, they are not entitled in priority over the appellants who are the deceased's blood relations. ${ }^{18}$

The fact of the case relevant to this paper is that paternity was not conferred on the $2^{\text {nd }}$ to $4^{\text {th }}$ respondents (and the Letters of Administration granted to them) merely because there was elaborate representation as in (i) - (iv) above, that the non-biological children of the deceased were so conferred.

In other to avoid leaving the destiny of children born out of wedlock in the hands of the biological father, judicial pronouncements have shown that (in addition to acknowledgement of paternity by the intestate) the paternity of a child can be established to be on the intestate, by proof.

The case of Ukeje v. Ukeje supra, is illustrative of this point. In that case, one Lazarus Ogbonnaya Ukeje from Umuahia in Abia State of Nigeria (Imo State of Nigeria at the time of the suit) lived most of his life in Lagos State of Nigeria and died thereat, intestate on the $27^{\text {th }}$ day of December 1981, leaving some real property in Lagos State. The deceased got married to the $1^{\text {st }}$ defendant/ appellant on the $13^{\text {th }}$ day of December 1956 who begat the $2^{\text {nd }}$ defendant/appellant and three other children for the deceased.

18 Ratio 6. The judgment of the court was within the contemplation of the provision of Administration and Succession (Estate of Deceased Persons Law) Cap 4 Laws of Anambra State of Nigeria, 1991 which provides in its section 96 (2) that in grant of Letters of Administration, the order of priority, include in order of priority, the children of the deceased and the brothers and sisters of whole blood. In this case, the appellants were the brother and sister, respectively, of the deceased. 
Following the death intestate of the deceased, the $1^{\text {st }}$ and $2^{\text {nd }}$ defendants/appellants (wife and son of the deceased, respectively) applied for and obtained Letters of Administration, to administer the estate of the deceased. The $1^{\text {st }}$ plaintiff/respondent who was begotton for the deceased in Lagos on the $5^{\text {th }}$ day of July 1952 from another woman (the $2^{\text {nd }}$ plaintiff/respondent), sued at the High Court Lagos State of Nigeria ${ }^{19}$ seeking inter alia an order that the Letters of Administration granted the $1^{\text {st }}$ and $2^{\text {nd }}$ defendants/appellants and dated the $15^{\text {th }}$ day of June, 1982 be revoked and another issued to her and the $2^{\text {nd }}$ defendant/appellant. She also sought a declaration that she was the daughter of the deceased and entitled to partake of the estate of the deceased. She tendered as Exhibit H, the Certificate of Birth issued in evidence of her birth, where the mother (the $2^{\text {nd }}$ plaintiff/ respondent) supplied the information thereon, including that the $2^{\text {nd }}$ plaintiff/respondent was the mother of $1^{\text {st }}$ plaintiff/respondent, while the deceased was the father of the $1^{\text {st }}$ plaintiff/respondent.

The $1^{\text {st }}$ plaintiff/respondent also tendered the negative and photograph of herself and the deceased between 1978 and 1990, as Exhibits $\mathrm{M}$ and $\mathrm{M}^{1}$ and tendered the photograph of the $2^{\text {nd }}$ plaintiff/respondent and the deceased in the 1950s as Exhibit P. She tendered a guarantor's form filled by the deceased for her, when she wanted to obtain a new Passport, wherein, the deceased acknowledged that he was her father. It was admitted in evidence as Exhibit 3. In the lifetime of the deceased, the $1^{\text {st }}$ plaintiff/respondent married a German national, which mar-

19 Presided over by Fafiade, J. riage was dissolved in a court of law. In the court proceedings, the $1^{\text {st }}$ plaintiff/respondent was referred to as nee Ukeje. A copy of the judgment in the suit was tendered as Exhibit J.

The trial court gave judgment for the plaintiffs/respondents which was sustained at the Court of Appeal ${ }^{20}$ and the Supreme Court. On proof of the paternity of the $1^{\text {st }}$ plaintiff/respondent (which was one of the issues that featured in the three courts and indeed the main issue), the Supreme Court readily agreed with the two lower courts, that the $1^{\text {st }}$ plaintiff/respondent was able to prove that she was the daughter of the deceased, entitled to share in his estate.

This case of Ukeje v. Ukeje did not only show that the paternity of a child born out of wedlock can be established by proof but proceeded to reveal that the nature of proof could be by tendering of documents. Examples of such documents were given in the case as:

i. Birth Certificate: A birth certificate is a document that contains the date and birth of a person. The contents of birth certificate in the absence of evidence to the contrary is deemed to be true, irrespective of who the person is that gave the information contained therein. What is crucial is that the certificate must have been issued by the person who ought to do so. In the words of the Supreme Court,

a birth certificate is conclusive proof that the person named therein was born on the date stated and the parents are those spelt out in

\footnotetext{
$20 \quad$ Lagos Division
} 
the document. It does not really matter the person who gave information for the birth certificate to be issued... the fact remained that an authorized person issued the birth certificate ${ }^{21}$.

ii. Photographs: Negatives of photographs and the photographs produced from the negatives that support the believable, oral evidence of a person as to their paternity are sufficient to establish the paternity of a person as vesting on the one that the negative and photographs so represent.

In this case, the photograph of the mother of the $1^{\text {st }}$ plaintiff/respondent and the deceased. The Supreme Court stated that although the trial court resolved the issue of paternity in favour of the $1^{\text {st }}$ plaintiff/respondent based on the birth certificate, the photographs might have contributed to the resolution of the issue of paternity in favour of the $1^{\text {st }}$ plaintiff/respondent, by the trial court. According to the Supreme Court,

... on the issue of whether the respondent was the daughter of L.O. Ukeje (deceased), family photographs may have helped to resolve the issue, but the birth certificate of the respondent was decisive in settling the issue ${ }^{22}$.

iii. Forms: Where in filling a form an alleged father has stated that he was the father of the person who was alleging that their paternity is on the person who

$21 \quad$ Ratio 2

22 Ratio 3 filled the form and stated that he was the father, there is a conclusive proof of paternity. On the facts of the case, the deceased filled a guarantor's form for the $1^{\text {st }}$ plaintiff/respondent wherein he stated that he was the father.

Stating that that acknowledgement in the form established that paternity of the $1^{\text {st }}$ plaintiff/respondent was on L.O Ukeje (deceased), the court stated that "the guarantor's form signed by the deceased (L.O. Ukeje) further showed that the deceased was the father of the respondent" ${ }^{23}$.

In addition to establishing the paternity of a child by documentary evidence (examples of which have been given to include birth certificates, photographs and forms), the paternity of a child could be proved by scientific tests and results, that paternity is on the person so alleged by the child. This has been provided for in the Child's Rights Act ${ }^{24}$. According to the Act:

In any civil proceedings in which the paternity or maternity of a person falls to be determined by the court hearing the proceedings, the court may, on application by a party to the proceedings give a direction (sic)for the use of scientific tests, including blood tests and Deoxyribonucleic Acid tests to show that a party to the proceedings is or is not the father or mother of that per$\operatorname{son}^{25}$.

This provision of the Act shows that scientific tests and results can be used to establish the paternity as well as the maternity of a person. The phraseology of the provision states that scientific tests could be used to show that paternity or maternity

\footnotetext{
23 Ibid.

24 Cap C50, Laws of the Federation of Nigeria, 2010

25 Ibid., section 63 (1) (a)
} 
is or is not on "a party to the proceedings" giving the impression that the test cannot be employed in intestate proceedings as the father or mother suspected to be that of the person in the suit is dead and cannot be "a party to the proceedings". This narrow interpretation cannot be given to this laudable provision of the Act for to do so would shut out persons (especially those born out of wedlock) from establishing that the deceased father or mother was theirs. It is suggested that the test should be employed to determine whether the paternity or maternity of a person vests on a party who may or may not be part of the proceedings ${ }^{26}$.

\section{CONCLUSION}

The right of children born out of wedlock enures when the intestate had acknowledged that paternity was on him. The acknowledgement certifies such children as qualified to partake of the estate of their common father in equal shares with their siblings born in the matrimonial home. The relevance of acknowledgement is to make known that the children born out of wedlock are the biological children of the intestate just as those born within the matrimonial home.

In the absence of acknowledgement there would be no paternity. This has produced the unfortunate circumstance where biological children born out of wedlock

26 Where the alleged father or mother is alive and participating in the proceedings, a direction may be given by the court for his or her blood sample and that of the claimant be taken and tested and thereafter, the result tendered in evidence. Where on the other hand, the alleged father or mother is late and not participating in the proceedings, a result of the test conducted on the blood sample of the alleged father or mother in his/her life and on the blood sample of the claimant should be tendered and admitted in evidence as well. could not partake of the estate of their biological father, with their siblings born in the matrimonial home. This unfortunate circumstance has been weakened by allowing paternity to be established by documentary evidence, as pronounced by the Supreme Court in Ukeje v. Ukeje or by scientific tests and results as provided for in section 63 (1) (a) of the Child's Rights Act.

So far, what now exists is the proof with ease, of the paternity of children born out of wedlock and the readily available right of such children to inherit from the estate of the intestate in equal shares with their siblings born in the matrimonial home. The effect has been the compliance with the constitutional provision that no citizen of Nigeria shall suffer discrimination due to circumstances of their birth. While the state of the law is well appreciated, it is hoped that this would not encourage promiscuity as such act is undoubtedly contrary to public policy. ${ }^{27}$

\section{BIBLIOGRAPHY}

Child's Rights Act Cap C.50. (2010). Laws of the Federation of Nigeria.

Court of Appeal Enugu Division in Mgbo$d u$ v. Mgbodu (2015) 12 N.W.L.R (pt 1474) 415 ratio 3

27 See the unreported case of Re Adadevoh, Suit No: AL/68/1952. See also, Cole v. Aknyele (1960) 5 F.S.C 84. In Okonkwo v. Okagbue supra, Ogundare J.S.C. at page 343 had this to say on the contention that the six children born by the $3^{\text {rd }}$ respondent, thirty years after the death of the deceased were the children of the deceased, "to claim further that the children the $3^{\text {rd }}$ defendant had by other man or men are the children of Okonkwo deceased is nothing but an encouragement to promiscuity ... I have no hesitation in fining that anything that offends against morality is contrary to public policy and repugnant to good conscience. 
Okonkwo v. Okagbue (1994) 9 NWLR (pt 368) 301-346

Re Adadevoh, Suit No: AL/68/1952. See also, Cole v. Aknyele (1960) 5 F.S.C
84. In Okonkwo v. Okagbue supra, Ogundare J.S.C.

Ukeje v. Ukeje (2014) 11 NWLR (pt 1418) 384-414. 